\title{
PENGEMBANGAN KOMPETENSI PROFESIONAL GURU IPS (STUDI KASUS DI SMP PEMBANGUNAN LABORATORIUM UNP KOTA PADANG)
}

\author{
Rosa putriana \\ Program Studi Geografi \\ Fakultas Ilmu Sosial Universitas Negeri Padang \\ Email :chaaa_moeth@yahoo.com
}

\begin{abstract}
ABSTRAK
Penelitian ini bertujuan untuk mendapatkan data dan informasi tentang pengembangan kompetensi profesional guru IPS di SMP Pembangunan Laboratorium UNP berkaitan dengan pengembangan kompetensi profesional guru IPS SMP Pembangunan Laboratorium UNP dan Kendala-kendala dalam pengembangan kompetensi profesional guru IPS SMP Pembangunan Laboratorium UNP. Jenis penelitian ini adalah deskriptif kualitatif. Informan dalam penelitian ini adalah guru IPS SMP Pembangunan Laboratorium UNP yang berjumlah 4 (empat) orang. Instrumen penelitian yang digunakan dalam penelitian ini adalah pedoman wawancara, analisis dokumentasi dan observasi. Hasil penelitian menunjukkan bahwa pengembangan kompetensi profesional guru dilakukan dengan cara aktif mengikuti kegiatan seminar, musyawarah guru mata pelajaran (MGMP), pendidikan dan pelatihan guru, serta lokakarya-lokakarya, melalui kegiatan tersebut nantinya diaplikasikan kedalam pengembangan perencanaan pembelajaran, penggunaan media, teknologi dan komunikasi dalam pembelajaran serta evaluasi pembelajaran, kendalakendala dalam pengembangan komptensi professional guru sebagia besar disebabkan oleh minimnya kesempatan untuk mengikuti kegiatan-kegiatan yang berhubungan dengan pengembangan kompetensi professional guru, disamping masalah dana dan fasilitas yang tersedia.

Kata Kunci : Kompetensi Profesional, Guru IPS
\end{abstract}

\section{ABSTRACT}

This study aims to obtain data and information about the development of professional competence of IPS teachers in SMP Development Laboratory UNP related to the development of professional competence of teachers IPS SMP Development Laboratory UNP and Constraints in the development of professional competence of teachers IPS SMP Development Laboratory UNP. The type of this research is descriptive qualitative. Informant in this research is teacher of IPS SMP Development Laboratory of UNP which amounts to 4 (four) people. The research instruments used in this research are interview guide, documentation analysis and observation. The result of the research indicates that the development of professional competence of teachers is done by actively participating in seminar activities, Teachers Consultative Subject (MGMP), Education and training of teachers, and also with workshops, through these activities will be applied into the development of learning planning, the use of media, technology and communication in learning and learning evaluation, constraints in the development of professional competence of teachers is greatly due to the lack of opportunities to follow activities related to the development of professional competence of teachers, in addition to funding problems and facilities available.

Keywords: Professional Competence, IPS Teachers

${ }^{1}$ Artikel ini ditulis dari skripsi penulis dengan judul Pengembangan Kompetensi Profesional Guru IPS (Studi kasus di SMP Pembangunan Laboratorium UNP Kota Padang ) periode Maret 2018 dengan Pembimbing I, Dra. Yurni Suasti ,M.Si dan Pembimbing II Nofrion, S.Pd, M.Pd 


\section{PENDAHULUAN}

Undang-undang

Sistem

Pendidikan Nasional Nomor 20

Tahun 2003 Pasal 27 Ayat 1 bagian $\mathrm{f}$ yang berbunyi bahwa "kurikulum pendidikan dasar dan menengah wajib memuat mata pelajaran IPS". Mata pelajaran IPS menjadi mata pelajaran yang peranannya sangat diharapkan menjadi maksimal dalam pembentukan sikap, berbangsa dan bernegara serta kemampuan menyesuaikan diri dalam masyarakat sosial.

Mata pelajaran Ilmu Pengetahuan Sosial (IPS), sebagai mata pelajaran yang wajib ditempuh oleh peserta didik, merupakan mata pelajaran yang disusun secara sistematis, komprehensif, dan terpadu sebagaimana yang tertuang dalam Permendiknas Nomor 22 Tahun 2006. Pembelajaran IPS yang disusun secara terpadu, memiliki tujuan agar peserta didik dapat memperoleh pemahaman yang lebih luas dan mendalam pada bidang ilmu yang berkaitan. Oleh sebab itu, pembelajaran IPS di tingkat SMP dan MTSN di Indonesia seharusnya menerapkan pembelajaran IPS secara terpadu.

\section{Secara}

sistematis,

komprehensif, dan terpadu sebagaimana yang tertuang dalam Permendiknas Nomor 22 Tahun 2006. Pembelajaran IPS yang disusun secara terpadu, memiliki tujuan agar peserta didik dapat memperoleh pemahaman yang lebih luas dan mendalam pada bidang ilmu yang berkaitan. Oleh sebab itu, pembelajaran IPS di tingkat SMP dan MTSN di Indonesia seharusnya menerapkan pembelajaran IPS secara terpadu.

Kurikulum 2013 disusun dengan maksud antara lain untuk mengembangkan potensi peserta didik menjadi kemampuan dalam berfikir reflektif dalam penyelesaian masalah sosial di masyarakat. Kurikulum 2013 dikembangkan dengan menyempurnakan pola pikir dari pembelajaran pasif menjadi pembelajaran kritis. Pembelajaran yang semula berpusat pada guru menjadi pembelajaran yang berpusat pada peserta didik, yang semula satu arah menjadi pembelajaran interaktif.

Penerapan kurikulum tingkat satuan pendidikan ( KTSP ) pada mata pelajaran IPS terpadu diharapkan dapat menciptakan kondisi belajar yang efektif, dinamis dan tidak membosankan. Anggapan selama ini bahwa penggabungan mata pelajaran yang semula berdiri sendiri membuat siswa menjadi bingung. Dengan adanya penerapan pembelajaran IPS Terpadu berdasarkan KTSP dimana guru memiliki kewenangan mengembangkan sendiri kurikulumnya yang disesuaikan dengan kebutuhan peserta didik, potensi dan minat serta tujuan sekolah, maka diharapkan akan tercipta sistem pembelajaran IPS 
terpadu yang menyenangkan dan tidak membingungkan.

Dalam proses pembelajaran guru IPS harus memiliki wawasan yang luas karena IPS merupakan perpaduan dari sejumlah mata pelajaran sosial sehingga dalam mata pelajaran IPS tersebut menggunakan bagian-bagian tertentu dari ilmu-ilmu sosial dan sebuah bidang keilmuan yang dinamis, karena mempelajari tentang keadaan masyarakat yang cepat perkembangannya. Pengembangan kurikulum IPS merupakan jawaban terhadap tuntutan kebutuhan masyarakat yang akan mempelajarinya.

Guru IPS SMP merupakan guru yang sekaligus harus menguasai bidang keilmuan sosial secara keseluruhan karena pembelajaran IPS merupakan perpaduan dari pelajaran geografi, ekonomi dan sejarah sehingga disini dituntut kompetensi profesional guru IPS. Kompetensi profesional adalah kemampuan guru dalam menguasai materi pembelajaran secara luas dan mendalam, dengan demikian, guru harus memiliki pengetahuan yang luas (Euis dan Doni, 2014:77).

Di kota Padang sendiri hampir setiap sekolah menengah pertama tidak menerapkan IPS terpadu berdasarkan KTSP sebagai usaha untuk meningkatkan kualitas pembelajaran. Dalam kenyatannya di lapangan banyak guru IPS yang kurang menguasai materi yang akan diajarkan. Hal ini dikarenakan latar belakang guru yang berbeda-beda. Padahal dalam pembelajaran IPS terpadu guru dituntut untuk menguasai materi yang akan diajarkan baik itu geografi, sejarah, ekonomi, dan sosiologi. Dengan adanya hal ini guru IPS mau tidak mau harus dituntut untuk belajar lagi guna menguasai materi yang akan di ajarkan hal ini tentunya sangat berpengaruh besar terhadap hasil belajar yang akan dicapai oleh siswa permasalahan lain yang ditemukan oleh peneliti yaitu pada saat ini pelaksanaan pembelajaran di SMP untuk mata pelajaran IPS masih dilakukan secara terpisah. Seharusnya pembelajaran IPS merupakan pembelajaran tematik dimana pembelajaran tematik melibatkan beberapa mata pelajaran dalam satu tema untuk memberikan pengalaman bermakna bagi siswa. Pengalaman bermakna maksudnya siswa memahami konsep - konsep yang telah mereka pelajari itu melalui pengalaman langsung dan menghubungkannya dengan konsep lain yang sudah mereka pahami (Depdikbud Hilda, 2012).

Pembelajaran tematik ini berorientasi pada kebutuhan perkembangan anak artinya sebagai dasar pembentukan pengetahuan dan struktur intelektual anak. Jika dibandingkan dengan pembelajaran konvensional maka pembelajaran tematik lebih menekankan keterlibatan siswa secara aktif baik kognitif maupun skill dalam proses 
pembelajarannya. Prinsip "Belajar seraya bermain dan Learning by doing” diterapkan dalam pembelajaran tematik. Pembelajaran tematik adalah pembelajaran terpadu yang menggunakan tema untuk mengaitkan beberapa mata pelajaran sehingga dapat memberikan pengalaman bermakna kepada siswa. Tema adalah pokok pikiran atau gagasan pokok yang menjadi pokok pembicaraan (Poerwadarminta, 1983).

Guru IPS harus memiliki kompetensi profesional karena harus menguasai materi IPS secara keseluruhan pada umumnya dan bidang keilmuan yang diampunya pada khususnya dimana pembelajaran IPS di SMP merupakan pembelajaran tematik dan terpadu dari materi pelajaran sejarah, ekonomi dan geografi. Oleh karena itu setiap guru IPS harus memiliki upaya-upaya dalam pengembangan kompetensi profesionalannya dalam pembelajaran IPS sehingga pembelajaran IPS di SMP tidak lagi pembelajaran yang semata-mata hanya ceramah dan peserta didik pada akhirnya hanya menghafal materi-materi dan hanya akan bertahan lama dalam waktu yang singkat dalam mengingat dan tidak bisa mengaitkan antara sejarah, geografi dan ekonomi dalam pengaplikasiannya bagi kehidupan sehari-hari. Oleh karena itu guru IPS harus mampu mengembangkan keprofesionalannya dalam memberikan pemahaman yang mendalam ke siswa bukan siswa disuruh menghafal keseluruhan materi IPS.

SMP Pembangunan Laboratorium UNP adalah SMP labor satu- satunya di Sumatra Barat yang memiliki keunggulan tersendiri, oleh karena itu guru yang berada di SMP tersebut harus memiliki kompetensi profesional yang mendukung dan berkualitas sehingga penulis merasa tertarik untuk menelusuri pengembangan kompetensi profesional SMP Pembangunan Laboratorium UNP Kota Padang sebagai sebuah studi kasus.

Berdasarkan fakta- fakta lain yang penulis temui di lapangan bahwasannya guru IPS di SMP Pembangunan Laboratorium UNP Kota Padang sebagian besar tidak menggunakan media dalam proses belajar mengajar, hanya terpaku pada buku dan LKS (lembaran kerja siswa) sehingga siswa kurang mengerti dengan pembelajaran yang dilaksanakan dikelas.

Dalam proses belajar mengajar guru selalu menggunakan metode ceramah dan memberikan tugas di kelas sampai jam pelajaran habis, sehingga siswa merasa bosan dan menoton di dalam kelas. Padahal seharusnya guru IPS bisa menggunakan metode pembelajaran yang bervariasi dalam proses belajar mengajar yang membuat siswa dapat berperan aktif dan kreatif . 
Pada proses pembelajaran guru sering kehabisan waktu dalam memberikan materi yang disampaikan di kelas, artinya seorang guru IPS belum efektif dalam mengelola waktu pembelajaran, sehingga materi yang disampaikan tidak tercapai secara baik dan maksimal.

Dilihat dari pembuatan rencana pelaksanaan pembelajaran (RPP) tidak semua guru IPS disekolah SMP Pembangunan Laboratorium UNP Kota Padang yang membuat sendiri RPP tersebut. Guru hanya menyalin yang sudah ada saja sehinngga terkadang ada yang tidak sesuai dengan RPP nya.

\section{METODE PENELITIAN}

Jenis penelitian ini adalah penelitian kualitatif. Penelitian ini dilakukan di SMP Pembangunan Laboratorium UNP Kota Padang.

Lokasi penelitian dapat dilihat pada gambar 1 dibawah ini

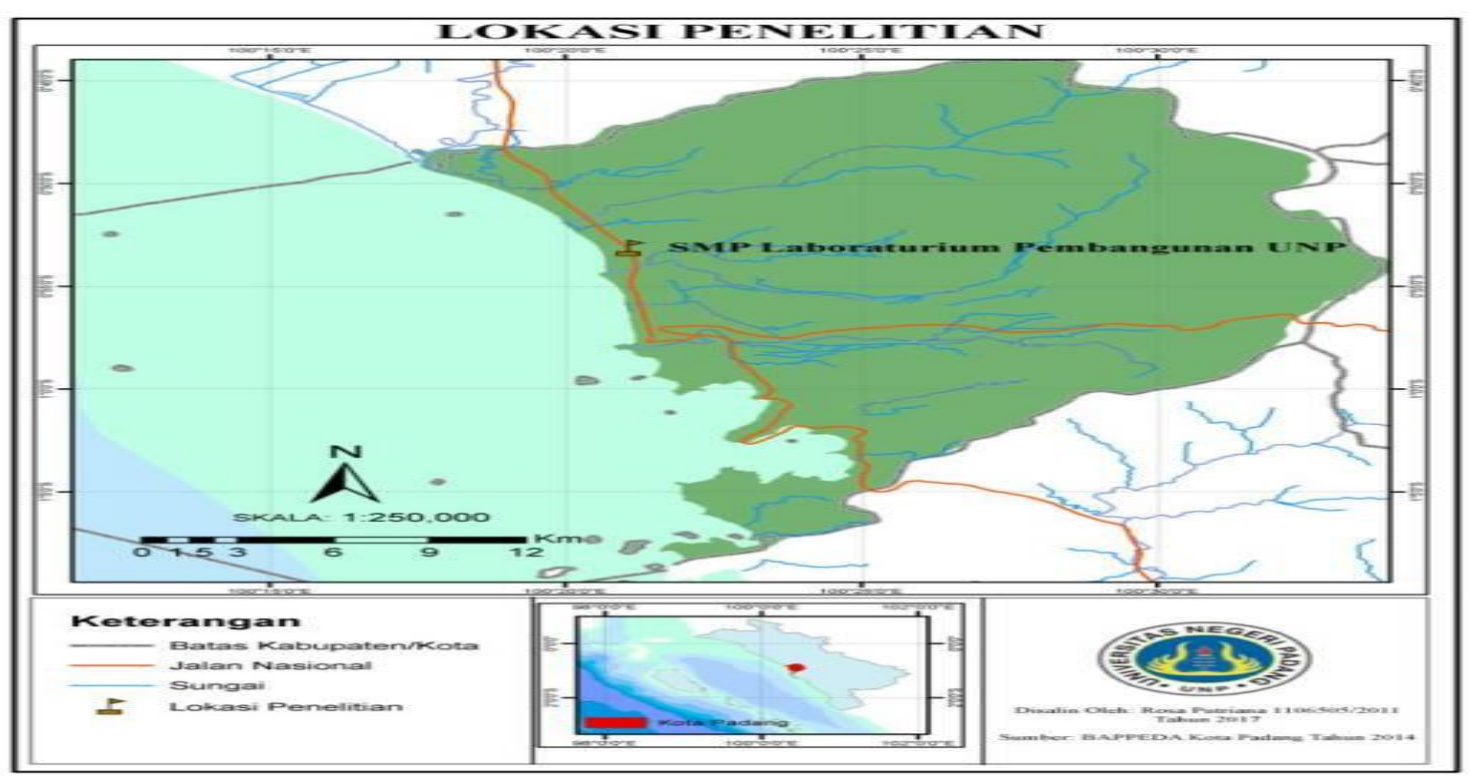

Subjek penelitian terdiri dari empat orang guru IPS di SMP Pembangunan Laboratorium UNP Kota Padang.

Dalam pengambilan data peneliti melakukan penelitian langsung kelapangan, melakukan wawancara terhadap informan, mencatat hasil wawancara dan menggunakan kamera sebagai alat untuk mengabadikan proses penelitian berlangsung. Agar data yang diperoleh dapat dipertanggung jawabkan, dapat diuji kebenarannya dan terpercayaanya suatu data yang diperoleh dalam penelitian maka dilakukan triangulasi . 
Triangulasi berarti pengecekan kepercayaan penemuan hasil penelitian dengan beberapa cara pengambilan data dan pengecekan kepercayaan penemuan hasil informan (sumber data). Untuk memeriksa kembali data-data yang telah diperoleh dengan mengkombinasikan teknik observasi, wawancara dan dokumentasi.

Teknik analisis data menggunakan model analisis data yang dikemukakan oleh Miles dan Hubberman dalam Sugiyono (2008:246) yang terdiri dari proses reduksi data, penyajian data atau display data dan penarikan kesimpulan.

\section{HASIL PENELITIAN DAN PEMBAHASAN}

Berdasarkan hasil penjelasan
dengan informan sebelumnya keikutsertaan informan dalam hal ini Bapak David Rhicardo, S.Pd dalam pelatihan pengembangan kompetensi profesional guru adalah seminar, diklat dan lokakarya, dengan tema pengembangan mutu pendidikan dan pembelajaran. Kegiatan tersebut dilaksanakan di hotel maupun di sekolah sendiri dengan jangka waktu sekali pertemuan hingga beberapa kali pertemuan. Pemateri dalam hal ini berasal dari guru sekolah dan instansi pendidikan, dengan pembiayaan sendiri, sekolah dan dana biaya operasional sekolah (BOS). $\begin{array}{lcr}\text { Hasil } & \text { wawancara } & \text { diatas } \\ \text { menunjukkan } & \text { bahwa } & \text { dalam } \\ \text { keikutsertaan } & \text { guru IPS } & \text { dalam } \\ \text { pengembangan } & \text { dan } & \text { pelatihan }\end{array}$ kompetensi profesonal guru yaitu dengan informan Ibu Revi Heriani, S.Pd adalah dengan mengikuti seminar, diklat, MGMP dan lokakarya. Kegiatan tersebut dilaksanakan dalam jangka waktu Mei sampai dengan Agustus 2017 dengan tema kurikulum 2013 serta pengembangan bahan ajar dengan pemateri berasal dari sekolah sendiri, lembaga penjamin mutu pendidikan (LPMP) dan dari Instansi Dinas Pendidikan. Kegiatan tersebut dilaksanakan dengan biaya dari sekolah. LPMP dan dari dinas pendidikan.

Berdasarkan hasil penelitian pada sekolah SMP Pembangunan Laboratorium UNP kota Padang pada tahun ajaran 2016/2017 bahwa guru IPS dalam mengikuti pengembangan kompetensi profesional guru seperti seminar, MGMP, diklat, lokakarya hanya 1-4 kali dalam setahun.

Dari hasil penelitian yang peneliti lakukan di SMP Pembangunan Laboratorium UNP Kota Padang, terdapat beberapa indikator seperti: seminar, diklat, MGMP, lokakarya. Kegiatan tersebut sering terkendala dengan waktu jam pelajaran yang bentrok, oleh sebab itu guru SMP Pembangunan Laboratorium UNP Kota Padang tidak dapat mengikuti kegiatan pengembangan kompetensi 
profesional guru melalui seminar, MGMP, diklat, lokakarya secara maksimal.

Jika dilihat dari frekuensi keikutsertaan guru IPS di SMP Pembangunan Laboratorium UNP Kota Padang dalam pengembangan kompetensi profesional guru pada tahun ajaran 2016-2017 sebagai berikut, dalam mengikuti seminar tiga orang guru mengikuti kegiatan seminar hanya satu kali dalam setahun, kemudian yang mengikuti kegiatan seminar dua kali hanya satu orang guru dalam setahun. Selanjut dalam kegiatan diklat (pendidikan dan latihan ) ada satu orang guru yang tidak pernah ikut sama sekali kegiatan diklat, kemudian satu orang guru yang pernah melakukan diklat hanya sekali, sedangkan guru yang mengikuti kegiatan diklat dua kali dalam setahun berjumlah dua orang guru IPS. Kemudian kegiatan MGMP ada satu orang guru yang mengikuti kegiatan ini hanya sekali dalam setahun ada juga satu orang guru yang mengikuti MGMP empat kali selama setahun. Berikutnya kegiatan Lokakarya yang diikuti guru IPS hanya dua kali selama setahun dan ada juga dua orang guru IPS yang mengikuti empat kali lokakarya dalam setahun.

Berdasarkan hasil penelitian pengembangan kompetensi profesional guru IPS di SMP Pembangunan Laboratorium UNP Kota Padang dilakukan dengan berbagai cara.
Pertama, keikutsertaan guru IPS SMP Pembangunan Laboratorium UNP dalam pengembangan dan pelatihan kompetensi profesional guru adalah seperti megikuti seminar, pendidikan dan pelatihan (diklat), MGMP, dan lokakarya. Pelaksanaan kegiatan tersebut dilakasanakan oleh sekolah sendiri, dinas pendidikan dan LPMP dengan pemateri berasal dari kalangan guru, dosen, dan dinas pendidikan.

Kedua, pengembangan kompetensi profesional guru yaitu pengembangan silabus dan RPP sendiri sesuai dengan perkembangan zaman, dimana pengembangan tersebut dilaksanakan oleh guru IPS dengan kondisi belajar dan kebutuhan pembelajaran, selain itu juga dilakukan melaui kegiatan musyawarah guru mata pelajaran (MGMP) dan lokakarya.

Ketiga, pengembangan kompetensi profesional guru yaitu melalui kegiatan membaca bermacam-macam buku terkait mata pelajaran yang diampu untuk menambah pengetahuan dan wawasan dilakukam oleh guru IPS dengan membaca dari berbagai sumber seperti koran, buku pegangan internet dan media lainya sesuai dengan kebutuhan proses pembelajaran.

Keempat, pengembangan kompetensi profesional guru melalui kegiatan kompetensi keguruan. Pada guru IPS di SMP Pembangunan 
Laboratorium UNP Kota Padang menunjukkan secara umum belum pernah mengikuti kegiatan kompetensi tersebut.

Kelima, pengembangan kompetensi Profesional guru tentang pelaksanaan penelitian tindakan kelas (PTK) dalam pembejaran adalah dimana secara umum guru belum pernah melaksanakan penelitian tindakan kelas, dikarenakan faktor ketidak sesuaian antara RPP dengan kondisi di kelas, dan lama mengajar.

Keenam, pengembangan kompetensi profesional guru IPS SMP terkait kemampuan penggunaan teknologi dan komunikasi dalam menunjang pembelajaran dilakukan melalui penggunaan media pembelajaran berbasis teknologi seperti penggunaan proyektor dan media pembelajaran tiga dimensi lainya yang disesuaikan dengan lingkungan dan situasi pembelajaran.

Kendala yang dialami para guru untuk mengembangan kompetensi profesional selain pembagian atau manajemen waktu, kendala tersebut antara lain,

Waktu merupakan faktor terpenting yang dijadikan patokan dan kesempatan untuk bisa melakukan sesuatu yang lebih baik. Hal ini juga berlaku bagi para guru dalam mengembangkan kompetensi profesional. Seringkali keputusan dari sekolah membuat guru kurang maksimal dalam mengembangkan kompetensi profesionalnya. Hal ini berdampak buruk bagi upaya mengembangkan kompetensi profesional guru yang selalu terhambat. Kendala-kendala dalam pengembangan komptensi profesional guru sebagian besar disebabkan oleh minimnya kesempatan untuk mengikuti kegiatan-kegiatan yang berhubungan dengan pengembangan kompetensi profesional guru, disamping masalah dana dan fasilitas yang tersedia. Ada juga terkendala dengan bentroknya jam pelajaran dengan kegiatan pengembangan kompetensi guru.

\section{PENUTUP}

\section{Kesimpulan}

Pengembangan kompetensi professional guru IPS dilakukan secara aktif mengikuti kegiatan seminar, musyawarah guru mata pelajaran (MGMP), pendidikan dan pelatihan (Diklat) guru, serta dapat pula dengan lokakarya-lokakarya, melalui kegiatan tersebut nantinya diaplikasikan

kedalam pengembangan perencanaan pembelajaran, penggunaan media, teknologi dan komunikasi dalam pembelajaran serta evaluasi pembelajaran.

Kendala-kendala dalam pengebangan komptensi profesional guru sebagian besar disebabkan oleh minimnya kesempatan untuk mengikuti kegiatan-kegiatan yang berhubungan dengan pengembangan kompetensi profesional guru, 
disamping masalah dana dan fasilitas yang tersedia.

\section{Saran}

Diharapkan pengembangan kompetensi profesional melalui studi literatur dan penulisan karya tulis ilmiah perlu ditingkatkan. Sebaiknya pengembangan yang dipandang lebih efektif untuk mengembangkan kompetensi profesionalnya guru yakni melalui diklat. Namun, kesempatan diklat yang kurang, sehingga dapat diupayakan guru untuk mengadakan diklat sendiri dengan berkoordinasi dengan Dinas Pendidikan yang terkait maupun bekerjasama dengan instansi yang terkait.

\section{DAFTAR RUJUKAN}

Undang-Undang Republik Indonesia Nomor 20 Tahun 2003, Tentang Sistem Pendidikan Nasional, Jakarta: Dirjen Pendidikan Dasar dan Menengah.

Peraturan Menteri Pendidikan Nasional Nomor 22 Tahun 2006, Tentang Standar Isi.

Euis dan Doni. 2014:77. Kompetensi profesional. Jakarta: Rineka Cipta.
Departemem Pendidikan Nasional

Hilda. 2012. Pengertian

Pembelajaran

Miles dan Huberman . 2008:246.

Teknik Analisis Data . Bandung : Remaja. Rosdakarya.

Poerwadarminta. 1983.

Pembelajaran Tematik. Jakarta : Dirjen Dikti Depdiknas.

Sugiyono. 2008. Metode Penelitian Kuantitatif, Kualitatif Dan $R$ $\& D$. Bandung: Alfabet. 